Research Paper

\title{
Determinants of migration of farmers: The case of Sira taluk in Karnataka
}

See end of the paper for authors' affiliations

Correspondence to : BI. AFRIN ZAINAB Department of Agricultural Economics, University of Agricultural Sciences, BENGALURU (KARNATAKA) INDIA Email: afrinzainab $22 @$ gmail.com

\section{Paper History :}

Received : 01.03.2017;

Revised : 25.07.2017;

Accepted : 05.08.2017
Abstract : A research study was undertaken in Sira Taluk of Karnataka to find out the factors determining the decision of farm family members to migrate and to analyse the income distribution pattern among migrant members. Primary data collected from sample farm house holds was subjected to- statistical analyses to study the income distribution and Logistic regression technique was used to determine the factors affecting the decision of farm family members to migrate. The research results revealed that 25 per cent of households reported to have migrant members and about five per cent reported migration of more than one family member. Rainfed farmers showed higher tendencies to migrate $(31.66 \%)$ than irrigated farmers $(21.66 \%)$. Decision to migrate was affected positively by number of persons per family. Farm income had negative influence on migration in rainfed situation, whereas it was a insignificant factor in case of irrigated farmers.

KEY WordS : Migration, Rainfed, Irrigated, Farm income, logistic regression

How To Cite This PAper : Zainab, Bi Afrin, Murthy, P.S. Srikantha, Rashmi, K.S. and Gowda, H.R. Chikkathimme (2017). Determinants of migration of farmers: The case of Sira taluk in Karnataka. Internat. Res. J. Agric. Eco. \& Stat., 8 (2) : 305-309, DOI : 10.15740/HAS/IRJAES/8.2/305-309. 